九州大学学術情報リポジトリ

Kyushu University Institutional Repository

\title{
Characteristic of New Bacillus thuringiensis Strains with Insecticidal Activity Against Bradysia agrestis (Sciaridae: Diptera)
}

KIM, Hee Ji

Department of Applied Biology, College of Agriculture and Life Sciences, Chungnam National University

LEE, You Kyoung

Department of Applied Biology, College of Agriculture and Life Sciences, Chungnam National University

YOUN, Young Nam

Department of Applied Biology, College of Agriculture and Life Sciences, Chungnam National University

AOKI, Chisa

Laboratory of Insect Pathology and Microbial Control, Institute of Biological Control, Faculty of Agriculture, Kyushu University

他

https://doi.org/10.5109/2340915

出版情報：九州大学大学院農学研究院紀要. 64 (2)，pp. 267-273，2019-09-02. Faculty of Agriculture, Kyushu University

バージョン :

権利関係 : 


\title{
Characteristic of New Bacillus thuringiensis Strains with Insecticidal Activity Against Bradysia agrestis (Sciaridae: Diptera)
}

\author{
Hee Ji KIM ${ }^{1}$, You Kyoung LEE ${ }^{1}$, Young Nam YOUN ${ }^{1}$, \\ Chisa YASUNAGA-AOKI ${ }^{2 *}$ and Yong Man $\mathrm{YU}^{1 *}$
}

\author{
Laboratory of Insect Pathology and Microbial Control, Institute of Biological Control, \\ Faculty of Agriculture, Kyushu University, Fukuoka 819-0395, Japan \\ (Received May 7, 2019 and accepted May 8, 2019)
}

\begin{abstract}
Recently, as the number of farms that cultivate crops using organic compost in greenhouses has been increasing in South Korea, the occurrence of Bradysia agrestis have been coming to the fore seriously. The larvae of $B$. agrestis appear in the roots of various crops because their host range is wide and they cause serious damage to the crops as they suppress the growth and defoliate the crops. Therefore, the search for new biological control agents was investigated.

To screening new $B$. thuringiensis with high insecticidal activities against Diptera, three isolates that form spherical type crystals were selected from domestic soils. The $\mathrm{LC}_{95}$ value of $B$. thuringiensis strain CAB452, which is the most toxic to the larvae of Diptera B. agrestis among those three strains, was shown to be $4.4 \times 10^{7}(\mathrm{cfu} / \mathrm{ml})$. SDS-PAGE was performed to identify the $\delta$-endotoxin protein band pattern of $B$. thuringiensis strain CAB452 and the result indicated one main protein band of about $150 \mathrm{kDa}$. In order to investigate the proteins of the active toxin of this strain, this strain was treated with trypsin, which is a digestive enzyme, or $B$. agrestis larva triturated solution and as a result, one main band of about $50 \mathrm{kDa}$ was shown under each of the two conditions. PCR analysis of the crystal proteins of B. thuringiensis strain CAB452 revealed two genes, cry4A and cry9D.
\end{abstract}

Key words: Bacillus thuringiensis, Biological activity, Bradysia agrestis, Spherical crystal type

\section{INTRODUCTION}

Bradysia agrestis is an insect belonging to the genus Bradysia in the family Sciaridae in the order Diptera, which was first reported in watermelon seedlings in a greenhouse plantation in South Korea (Park et al., 1999). Diptera Bradysia occurs mainly in greenhouses, nurseries, and mushroom cultivation facilities and recently, the frequency of occurrences and damage have been rapidly increasing in seedling plantations for herbaceous ornamentals for garden plantation and home bonsai cultivation (Kim et al., 2001, 2012, 2013). In South Korea, 21 kinds of crops such as pepper, watermelon, melon, cucumber, tomato, strawberry, paprika, and chrysanthemum are recorded as host plants (Lee et al., 2001) and in foreign countries, 54 kinds such as begonia and carnation are recorded (Harris et al., 1995). In particular, the occurrences are severe in rockwoolcultured crops such as tomatoes and paprika and damage was identified in bulbs and tubers such as lilies and ginger, which are crops of which the roots are used. As such, the density of $B$. agrestis increases along with rich organic matter in soil and the humid greenhouse environments leading to severer damage (Lindquest et al., 1985). The symptoms of damage caused by larvae can-

${ }^{1}$ Department of Applied Biology, College of Agriculture and Life Sciences, Chungnam National University, Daejon 305-764, Korea

${ }^{2}$ Laboratory of Insect Pathology and Microbial Control, Institute of Biological Control, Faculty of Agriculture, Kyushu University, Fukuoka 819-0395, Japan

* Joint corresponding authors (E-mail: ymyu@cnu.ac.kr and yasunaga@grt.kyushu-u.ac.jp) not be easily observed with the naked eye because the larvae gnaw the roots or stems of plants as if they peel the roots or stems or penetrate into roots through root caps to do harm (Binns, 1973). In addition to direct damage, the larvae cause diseases by transmitting pathogenic bacteria such as Fusarium, Phoma, Pythium and Vericillium and the imagoes carry mycelia attached to their body such as the belly, legs and wings to transfer pathogenic bacteria to other plants or greenhouses thereby causing damage, (Ludwig and Oetting, 2001). $B$. agrestis is an insect pest that cannot be easily controlled because once it has begun to occur in greenhouses where crops are cultivated using organic matter, its eggs, larvae, pupae, and imagoes coexist in a short period of time or all instars except for imagoes inhabit soil or root tissues (Lindquist et al., 1985). To control this insect pest, registered chemical insecticides such as benfuracarb, diflubenzuron, fenthion, and teflubenzuron have been used (Kim et al., 2012, Kim et al., 2013). However, the use of insecticides is very limited due to problems such as the safety of the product, the appearance of resistant individuals, damage to humans and livestock, and the induction of environmental pollution (Jagdale et al., 2004). Therefore, studies are necessary on biological control, which is an alternative method to effectively control $B$. agrestis while being safe to environments (Kim et al., 2013). Until recently, B. thuringiensis strains, insect pathogenic nematodes, and predatory mites have been used for biological control of Diptera in the genus Badysia (Jeon et al., 2007) but studies on biological control factors for Diptera are still insufficient.

B. thuringiensis has been reported to have been 
isolated from every habitats around us, including soils, insects, leaves and conifer leaves, water, stored grain flour, and sericulture farms (Lee et al., 2014, 2015). B. thuringiensis, which is widely used as a microbial insecticide, is used as a major agricultural material in eco-friendly agriculture because it is safe to non-selective organisms (Lee et al., 2014, 2015). B. thuringiensis is an insect pathogenic bacterium, and aerobic grampositive bacilli that forms endogenous spores and produce insecticidal proteins composed of ?-endotoxin proteins. These insecticidal crystal proteins (ICPs) exhibit host specificities that differ in their toxicity to various insects such as lepidoptera, Diptera, and Coleoptera (Schnepf, 1995). In addition, their activity has also been reported for Hymenoptera, Hemiptera, Orthoptera, mite, nematodes, and protozoans (Lee et al., 2014, 2015). Interest in $B$. thuringiensis as a biological control agent is increasing worldwide, and $B$. thuringiensis subsp. israelensis strains that have high toxicity to Diptera larvae are mainly marketed as products to control Diptera insect pests (Seo et al., 2010). However, other microbial insecticides registered in order to control other Diptera insect pests are insufficient.

Therefore, in this study, new B. thuringiensis strains, which are new biological control agents with insecticidal activities in $B$. agrestis, which is becoming problematic because the area of greenhouse cultivation where crops are cultivated using organic agent is rapidly increasing, were selected and their biological characteristics were analyzed.

\section{MATERIALS AND METHODS}

\section{Isolation and identification of Bacillus thuring- iensis isolate}

A selection test was conducted with 50 strains which were searched and isolated from domestic soils and kept in the Biological Pest Control Laboratory of Chungnam National University. Those strains that form $\delta$-endotoxin proteins were selected by observation under a phase contrast microscope. The selected strains were diluted in sterilized water and evenly spread on a nutrient agar plate. The plate was incubated in a $27^{\circ} \mathrm{C}$ incubator for 3 to 4 days and after identifying that autolysis had occurred, the plate was centrifuged at 15,000 rpm for 15 minutes using a centrifuge (Avanti J-E, Beckman) to collect bacteria. Among the 10 isolated strains of $B$. thuringiensis, one strain with the highest insecticidal activities in Bradysia agrestis was sent to Mokwon University Micro-Ecological Resources Research Institute to conduct identification of the strain with flagellin $\mathrm{C}$ gene.

\section{Test insect}

The Diptera B. agrestis used in this experiment was bred using potatoes as feed, and the Aedes albopictus was bred using yeast extract added to fry feed (Kim et al., 2008). The insects were bred for successive generations in the biological pest control laboratory of Chungnam National University under the conditions of temperature $25 \pm 2{ }^{\circ} \mathrm{C}$, light condition 16L:8D, relative humidity 50-60\% (Kim et al., 2008). A. albopictus imagoes were supplied with $10 \%$ sugar water as feed, and $B$. agrestis imagoes were bred with the method of Jang et al. (2018).

\section{Bioactivity assay}

The 10 selected strains of $B$. thuringiensis were inoculated into a nutrient agar medium and cultured at $27^{\circ} \mathrm{C}$ for $5-6$ days. Thereafter, bacteria were collected while observing the formation of $\delta$-endotoxin crystal proteins under a phase contrast microscope and the collected bacteria were centrifuged. The supernatant was discarded, and $20 \mathrm{ml}$ of sterilized water was added to the remaining pellet for use in bioassay. In order to investigate insecticidal activities, experiments were conducted with a total of 11 strains, that is, 10 new strains held by the laboratory and B. thuringiensis subsp. israelensis strain.

The bioactivity test for $B$. agrestis in the family Sciaridae in the order Diptera was carried out by adding $200 \mu \mathrm{l}$ of the culture solution to $1 \mathrm{~g}$ of potato and placing 20 each of 3-4 days old larvae after hatching in each petri dish. This experiment was carried out in three repetitions and the mortality rates were investigated for 168 hours.

The bioactivity test for $A$. albopictus in the family Culicidae in the order Diptera was conducted with the experimental method presented by WHO (2005) with some modification. Ten each of larvae 3-4 days old after hatching were put into each $90 \mathrm{ml}$ plastic cup containing $30 \mathrm{ml}$ of water, and $0.3 \mathrm{ml}$ of the diluted bacterial solution was inoculated. The mortality rate was investigated for 72 hours, and the experiment was carried out in three repetitions.

\section{SDS-PAGE}

Each strain was inoculated on a nutrient agar medium and cultured at $27^{\circ} \mathrm{C}$ for 5 days. After identifying that autolysis had occurred with a phase contrast microscope, the bacteria were collected and centrifuged at $15,000 \mathrm{rpm}$ at $4^{\circ} \mathrm{C}$ for 10 minutes. After the centrifugation, the supernatant was discarded and the bacteria were washed twice with washing buffer I $(500 \mathrm{mM} \mathrm{NaCl}$, $2 \%$ Triton X-100) and three times with washing buffer II (500 $\mathrm{mM} \mathrm{NaCl})$ to remove some resistant spores while collecting $\delta$-endotoxin crystalline proteins. Thereafter, sterile water was added to the washed parasporal inclusions and $1 \mathrm{ml}$ each of the mixture was put into each $1.5 \mathrm{ml}$ and kept at $-20^{\circ} \mathrm{C}$. SDS-PAGE was conducted in the method of Laemmli (1970) with some modification using 12\% separating gel and 5\% stacking gel. After electrophoresis, the gel was stained with $0.5 \%$ Coomassie brilliant blue, decolored for 12 hours, and the results were identified.

\section{Plasmid DNA analysis}

The protocol of Qiagen midi kit was used after some modification to extract plasmid DNAs from the selected B. thuringiensis strains. Each of the strains was inocu- 
lated into $5 \mathrm{ml}$ of $\mathrm{LB}$ medium and cultured at $27^{\circ} \mathrm{C}$ and $180 \mathrm{rpm}$ for 8 hours. The culture solution was put into $50 \mathrm{ml}$ of LB medium and incubated for 16 hours under the same conditions. The cultured bacteria were centrifuged under the conditions of $6,000 \mathrm{~g}, 15$ minutes, and $4^{\circ} \mathrm{C}$. The supernatant was discarded, $4 \mathrm{ml}$ of $\mathrm{P} 1$ buffer (50 mM Tris-HCl, pH8.0, $10 \mathrm{mM}$ EDTA, $50 \mu \mathrm{g} / \mathrm{ml}$ of RNase A) was added to the pellet, and the pellet was dissolved by vortexing. Thereafter, $4 \mathrm{ml}$ of P2 buffer $(0.2 \mathrm{M}$ $\mathrm{NaOH}, 1 \%$ SDS) was added, the tube was turned upside down 4-6 times to mix the content, and the content was incubated in a $15-25^{\circ} \mathrm{C}$ incubator for 5 minutes. Then, $4 \mathrm{ml}$ of chilled P3 buffer (4 M guanidine hydrochloride, $0.5 \mathrm{M}$ potassium acetate, $\mathrm{pH} 4.2$ ) was added, the tube was turned upside down 4-6 times to mix the content, and the content was incubated in ice for 15 minutes. The content was centrifuged at $15,000 \mathrm{rpm}, 4^{\circ} \mathrm{C}$ for 30 minutes, and the supernatant was transferred to a new tube. After centrifugation at $15,000 \mathrm{rpm}$ at $4^{\circ} \mathrm{C}$ for 15 minutes, a Qiagen-tip 100 was placed horizontally, $4 \mathrm{ml}$ of QBT buffer (50 mM NaCl, $50 \mathrm{mM}$ MOPS, pH7.0, $15 \%$ isopropanol, $0.15 \%$ Triton $\mathrm{X}-100$ ) was put into the Qiagen-tip 100 to pass through it, and the centrifuged supernatant was put into the column. When the supernatant completely passed through the column, the Qiagen-tip 100 was washed twice with $10 \mathrm{ml}$ of QC buffer. The DNA was dissolved and isolated with $5 \mathrm{ml}$ of QF buffer and $3.5 \mathrm{ml}$ of isopropanol at room temperature was added to precipitate the DNA and the solution was centrifuged at $15,000 \mathrm{rpm}$ and $4^{\circ} \mathrm{C}$ for 30 minutes. The supernatant was discarded, $2 \mathrm{ml}$ of $70 \%$ ethanol was added to wash the DNA pellet, and the solution was centrifuged for 10 minutes at $15,000 \mathrm{rpm}$ at $4^{\circ} \mathrm{C}$. The supernatant was discarded, the DNA pellet was air-dried for 5 to 10 minutes, and $200 \mu \mathrm{l}$ of triple distilled water was added to dissolve the plasmid DNA again. The plasmid DNA was mixed with the triple distilled water, placed in a sterile Eppendorf tube, and stored at $-20^{\circ} \mathrm{C}$ until being used in the experiment. The electrophoresis was performed using the agarose gel made by mixing agarose gel in $1 \times$ TAE buffer at a ratio of $1 \%$, dissolving the gel by heating, and then pouring the gel into a gel tray, and allowing the gel to be hardened for 20 minutes. Thereafter, $1 \times$ TAE buffer, which is identical to the gel, was poured on the electrophoresis apparatus so that it came up about $3-5 \mathrm{~mm}$ above the gel, a mixed fluid made by mixing the loading dye and loading star at a ratio of 5:1 was mixed with the plasmid DNA sample at a ratio of 1:5. The mixture was put into individual wells, electrophoresed at $50 \mathrm{~V}$ for 60 minutes, and irradiated with UV to identify the band pattern.

\section{Plasmid DNA analysis}

The protocol of Qiagen midi kit was used after some modification to extract plasmid DNAs from the selected B. thuringiensis strains. Each of the strains was inoculated into $5 \mathrm{ml}$ of $\mathrm{LB}$ medium and cultured at $27^{\circ} \mathrm{C}$ and $180 \mathrm{rpm}$ for 8 hours. The culture solution was put into $50 \mathrm{ml}$ of LB medium and incubated for 16 hours under the same conditions. The cultured bacteria were centri- fuged under the conditions of $6,000 \mathrm{~g}, 15$ minutes, and $4^{\circ} \mathrm{C}$. The supernatant was discarded, $4 \mathrm{ml}$ of $\mathrm{P} 1$ buffer (50 mM Tris-HCl, pH8.0, $10 \mathrm{mM}$ EDTA, $50 \mu \mathrm{g} / \mathrm{ml}$ of RNase A) was added to the pellet, and the pellet was dissolved by vortex. Thereafter, $4 \mathrm{ml}$ of P2 buffer $(0.2 \mathrm{M}$ $\mathrm{NaOH}, 1 \%$ SDS) was added, the tube was turned upside down 4-6 times to mix the content, and the content was incubated in a $15-25^{\circ} \mathrm{C}$ incubator for 5 minutes. Then, $4 \mathrm{ml}$ of chilled P3 buffer (4 M guanidine hydrochloride, $0.5 \mathrm{M}$ potassium acetate, $\mathrm{pH} 4.2$ ) was added, the tube was turned upside down 4-6 times to mix the content, and the content was incubated in ice for 15 minutes. The content was centrifuged at $15,000 \mathrm{rpm}, 4^{\circ} \mathrm{C}$ for 30 minutes, and the supernatant was transferred to a new tube. After centrifugation at $15,000 \mathrm{rpm}$ at $4^{\circ} \mathrm{C}$ for 15 minutes, a Qiagen-tip 100 was placed horizontally, $4 \mathrm{ml}$ of QBT buffer ( $50 \mathrm{mM} \mathrm{NaCl}, 50 \mathrm{mM}$ MOPS, pH7.0, $15 \%$ isopropanol, $0.15 \%$ Triton $\mathrm{X}-100$ ) was put into the Qiagen-tip 100 to pass through it, and the centrifuged supernatant was put into the column. When the supernatant completely passed through the column, the Qiagen-tip 100 was washed twice with $10 \mathrm{ml}$ of QC buffer. The DNA was dissolved and isolated with $5 \mathrm{ml}$ of QF buffer and $3.5 \mathrm{ml}$ of isopropanol at room temperature was added to precipitate the DNA and the solution was centrifuged at $15,000 \mathrm{rpm}$ and $4^{\circ} \mathrm{C}$ for 30 minutes. The supernatant was discarded, $2 \mathrm{ml}$ of $70 \%$ ethanol was added to wash the DNA pellet, and the solution was centrifuged for 10 minutes at $15,000 \mathrm{rpm}$ at $4^{\circ} \mathrm{C}$. The supernatant was discarded, the DNA pellet was air-dried for 5 to 10 minutes, and $200 \mu \mathrm{l}$ of triple distilled water was added to dissolve the plasmid DNA again. The plasmid DNA was mixed with the triple distilled water, placed in a sterile Eppendorf tube, and stored at $-20^{\circ} \mathrm{C}$ until being used in the experiment. The electrophoresis was performed using the agarose gel made by mixing agarose gel in $1 \times$ TAE buffer at a ratio of $1 \%$, dissolving the gel by heating, and then pouring the gel into a gel tray, and allowing the gel to be hardened for 20 minutes. Thereafter, $1 \times$ TAE buffer, which is identical to the gel, was poured on the electrophoresis apparatus so that it came up about $3-5 \mathrm{~mm}$ above the gel, a mixed fluid made by mixing the loading dye and loading star at a ratio of 5:1 was mixed with the plasmid DNA sample at a ratio of 1:5. The mixture was put into individual wells, electrophoresed at $50 \mathrm{~V}$ for 60 minutes, and irradiated with UV to identify the band pattern.

\section{PCR analysis}

Gene-specific primer sets known to have activity in Diptera were used to identify the Cry-type gene among the $\delta$-endotoxin genes of the selected $B$. thuringiensis strains. PCR amplification was performed using Thermal Cycle C 1,000 TM (BIO-RAD). The reaction solution was prepared by mixing $17 \mu \mathrm{l}$ of distilled water, $1.0 \mu \mathrm{l}$ of template DNA, and $1.0 \mu \mathrm{l}$ of each primer set into a premix (Bioneer) containing a buffer component and dNTP and adjusting the final volume to $20 \mu \mathrm{l}$. PCR was conducted under conditions consisting of 30 cycles for $3 \mathrm{~min}$ at $95^{\circ} \mathrm{C}, 1 \mathrm{~min}$ at $95^{\circ} \mathrm{C}$, annealing for $1 \mathrm{~min}$ at $57^{\circ} \mathrm{C}$ and for 
5 min at $72^{\circ} \mathrm{C}$ to produce PCR product DNA. The product DNA produced as such was electrophoresed on 1.0\% agarose gel (Yang et al., 2011).

\section{RESULTS AND DISCUSSION}

\section{Selection and characterization of $B$. thuringiensis strains}

B. agrestis, which occurs in domestic greenhouses, causes serious damage by directly doing harm to the roots of crops or ornamental plants grown using organic agent on culture media or soil (Jagdale et al., 2004). Twenty one kinds of crops have been reported as host plants in South Korea (Lee et al., 2001) and 54 kinds have been recorded in foreign countries (Harris et al, 1995). Sticky traps are used at forms to control the imagoes that cause damage to the upper parts of crops but the population of $B$. agrestis cannot be completely controlled without controling the larvae that cause damage to roots. Therefore, to select new B. thuringiensis strains, which are biological control agents, effective for control of $B$. agrestis larvae, 50 strains that had been kept in the Biological Pest Control Laboratory of Chungnam National University were selected. The morphology of the toxin protein crystals of the cultured strains was examined under a phase contrast microscope. Of the strains, 12 did not form any toxin protein crystal and 28 that formed bipyramidal type toxin protein crystals were investigated. In addition, the remaining 10 strains were found to form spherical type toxin protein crystals known to have activity in Diptera. The 10 strains that form spherical type toxin protein crystals were selected and their insecticidal activities in $B$. agrestis in the family Sciaridae in the order Diptera and Aedes albopictus in the family Culicidae in the order Diptera were tested. According to the results, among the 10 strains, $B$. thuringiensis strains CAB463 and CAB467 had almost no effect in $B$. agrestis. In B. agrestis, B. thuringiensis strain CAB452 showed high insecticidal activities over 90\%, B. thuringiensis strains CAB117, CAB469 and CAB599 showed insecticidal activities over $70 \%$, and B. thuringiensis subsp. israelensis strain and B. thuringiensis strains CAB459, CAB462, CAB490 and CAB492 showed insecticidal activities of at least 50\%. In A. albopictus, B. thuringiensis subsp. israelensis strain and B. thuringiensis strains CAB117, CAB452 and CAB599 showed high insecticidal activities of over 90\%. Therefore, B. thuringiensis strains CAB117, CAB452, CAB599 that showed insecticidal activities of at least 70\% in both Diptera B. agrestis and A. albopictus were selected.

\section{Bioactivity assay}

B. thuringiensis strains CAB117, CAB452, CAB599 that showed insecticidal activities of at least $70 \%$ in both Diptera B. agrestis and A. albopictus were selected and the bioactivity of these strains were tested using $B$. thuringiensis subsp. israelensis strain held in the laboratory as a control (Table 1). According to the results, the $\mathrm{LC}_{95}$ values of $B$. thuringiensis strains CAB117, CAB599, and B. thuringiensis subsp. israelensis strain were at least $10^{8}(\mathrm{cfu} / \mathrm{ml})$ and that of $\mathrm{LC}_{95}$ value of israelensis strain was over $10^{8}(\mathrm{cfu} / \mathrm{ml})$ and the $\mathrm{LC}_{95}$ value of $B$. thuringiensis strain CAB452 was $4.4 \times 10^{7}$ (cfu/ml). In $A$. albopictus, the $\mathrm{LC}_{95}$ value of $B$. thuringiensis strain CAB452 was $4.2 \times 10^{6}(\mathrm{cfu} / \mathrm{ml})$ that of $B$. thuringiensis strain CAB599 was $3.9 \times 10^{7}(\mathrm{cfu} / \mathrm{ml})$ that of $B$. thuringiensis strain $\mathrm{CAB} 117$ was $2.6 \times 10^{7}$ (cfu/ml), and that of $B$. thuringiensis subsp. israelensis strain was $2.2 \times 10^{5}(\mathrm{cfu} / \mathrm{ml})$. Whereas B. thuring-

Table 1. Toxicity $\left(\mathrm{LC}_{95} *\right)$ of $B$. thuringiensis strain against $B$. agrestis and $A$. albopictus

\begin{tabular}{ccc}
\hline \multirow{2}{*}{ Strains } & \multicolumn{2}{c}{ Diptera } \\
\cline { 2 - 3 } & B. agrestis $(\mathrm{cfu} / \mathrm{ml})$ & A. albopicus $(\mathrm{cfu} / \mathrm{ml})$ \\
\hline CAB452 & $4.4 \times 10^{7}$ & $4.2 \times 10^{6}$ \\
CAB117 & $>10^{8}$ & $2.6 \times 10^{7}$ \\
CAB599 & $>10^{8}$ & $3.9 \times 10^{7}$ \\
B. thuringiensis \\
israelensis \\
Control
\end{tabular}

* $\mathrm{LC}_{95}$ (lethal concentration 95\%): Concentration of toxic substances in which $95 \%$ of test insect die.
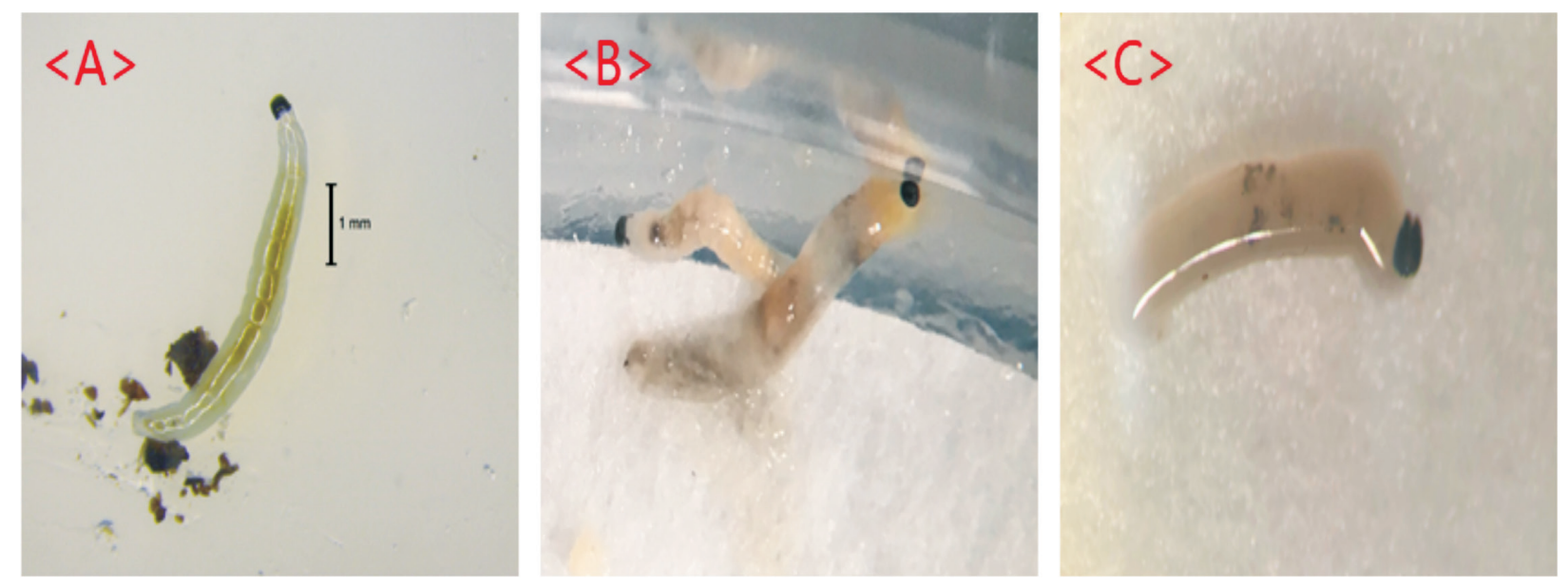

Fig. 1. The appearance of B. agrestis larva treated with B. thuringiensis CAB452. $<\mathrm{A}>$ : control; $\langle\mathrm{B}>$ : 3 days of dead larva; $<\mathrm{C}>$ : 5 days of dead larva. 
iensis strain $\mathrm{CAB} 117$ and $B$. thuringiensis subsp. israelensis strain showed low $\mathrm{LC}_{95}$ values in $A$. albopictus, strain CAB452 showed high insecticidal activities in both $B$. agrestis, which is in Diptera Sciaridae, and $A$. albopictus, which is in Diptera Culicidae. Therefore, $B$. thuringiensis strain CAB452 can be expected to be suitable as a biological control agent. It could be seen that whereas the larvae not treated with $B$. thuringiensis strain CAB452 had clearly visible mid-gut and transparent body, the larvae treated with $B$. thuringiensis strain CAB452 were infected with the train and the midgut became blurred and partially black and turbid at the third day after treatment (Fig. 1). On the seventh day after treatment with $B$. thuringiensis strain CAB452, the mid-gut was not visible and the larvae died while the whole body was turned black. In addition, although no experimental data was provided, the toxicity of $B$. thuringiensis strain CAB452 to Spodoptera exigua and Spodoptera litura was tested in order to identify the range of activity of $B$. thuringiensis strain CAB452 and the insects did not die in the tests.

\section{Morphological characteristics of $B$. thuringiensis strains}

To identify the crystal proteins of $B$. thuringiensis strain CAB452 with high insecticidal activities in Diptera insect pests, the strain was observed under a phase contrast microscope. According to the result, spherical type crystals, which are known to have insecticidal activities in Diptera pests, were formed. When compared with $B$. thuringiensis subsp. israelensis is strain, which shows activity in mosquitos, the spherical type crystals formed were quite similar. In addition, the crystals of $B$. thuringiensis strain CAB452 and B. thuringiensis subsp. israelensis strain were observed under a scanning electron microscope. Morphologically, spherical type crystals, known to have insecticidal activities in Diptera, were identified as with the observation under the phase contrast microscope (Fig. 2).

\section{SDS-PAGE}

In general, according to findings reported thus far, the crystal proteins produced by B. thuringiensis strains have molecular weights between 25 and $140 \mathrm{kDa}$ and are composed of $\delta$-endotoxin. Among the three types of crystal proteins formed by B. thuringiensis, the spherical type reported to have activity in Diptera pests has been reported to have molecular weights of $65 \mathrm{kDa}$ (Ibarra and Federici, 1986a, 1986b; Ibarra et al., 2003).

SDS-PAGE was performed to compare the characteristics of the $\delta$-endotoxin proteins of $B$. thuringiensis strain CAB452 that shows high insecticidal activities against Diptera $B$. agrestis and A. albopictus and $B$. thuringiensis subsp. israelensis strain known to have activity in Diptera. B. thuringiensis strain CAB452 showed a main protein band of about $150 \mathrm{kDa}$ in size. To identify the active toxin patterns of the parasporal inclu-

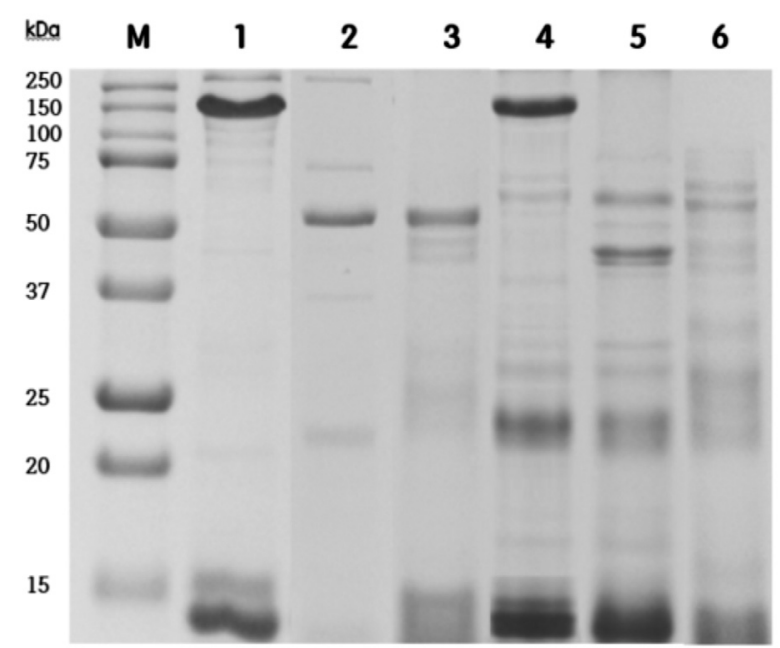

Fig. 3. SDS-PAGE analysis of parasporal incubation of $B$. thuringiensis isolates digested with trypsin. M: Standard Marker; lane 1: B. thuringiensis CAB452; lane 2: B. thuringiensis CAB452 digested with trypsin; lane 3: B. thuringiensis CAB452 digested with gut juice of $B$. agrestis; lane 4: B. thuringiensis subsp. israelensis; lane 5: B. thuringiensis subsp. israelensis digested with trypsin; lane 3: B. thuringiensis subsp. israelensis digested with gut juice of $B$. agrestis.
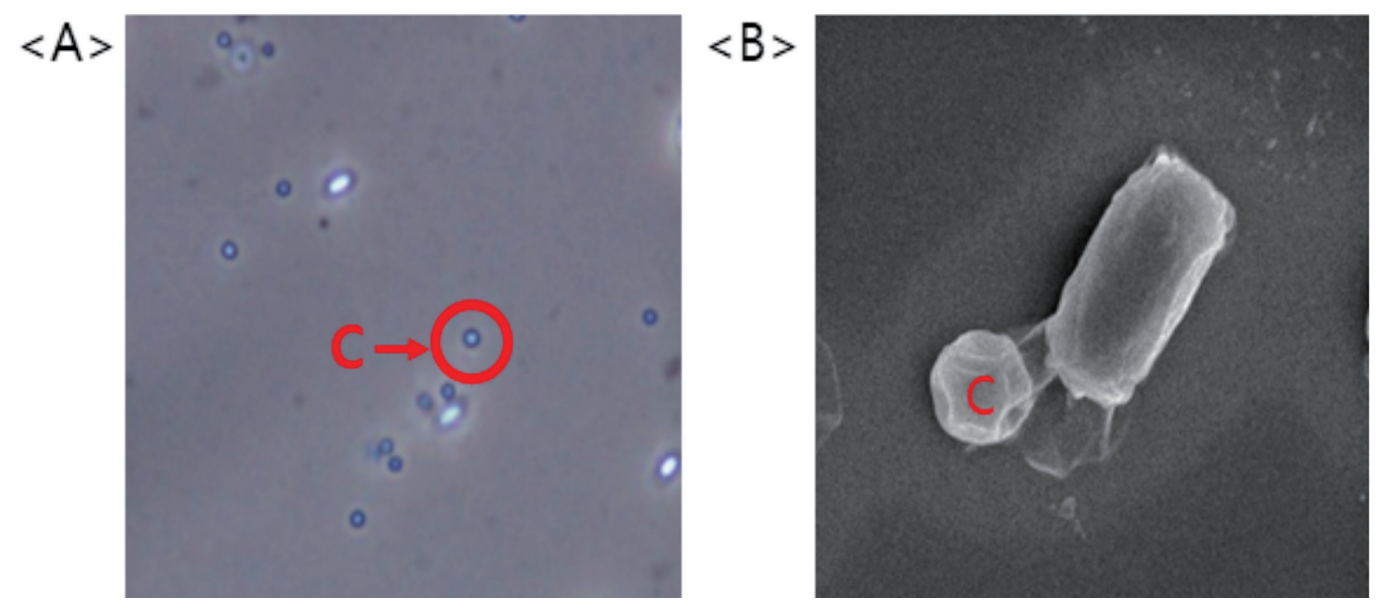

Fig. 2. $<A>$ : Phase-contrast microscope photographs $(\times 1,000)$ of crystal $(\mathrm{C})$ shape of $B$. thringiensis CAB452. $<$ B > : Scanning eletron microscopy of spore-crystal (C) mixtures of B. thringiensis CAB452. 
sions produced by the two strains, the strains were treated with trypsin, which is a digestion enzyme, and triturated solution of the entire $B$. agrestis larvae (since the gut cannot be separated as the larvae are too small) and the two treatments were compared (Fig. 3). It was shown that the $150 \mathrm{kDa}$ sized one main band of $B$. thuringiensis strain CAB452 was digested by trypsin or $B$. agrestis larvae triturated solution and only one $50 \mathrm{kDa}$ sized main protein band was formed. This is completely different from the protein molecular weights produced by other B. thuringiensis strains that shows toxicity to Lepidoptera or mosquito larvae reported thus far.

\section{Identification of Cry-type gene}

B. thuringiensis strain CAB452, which was selected because it was judged to be different from general $B$. thuringiensis strains based on the results of tests of insecticidal activities in Diptera and comparison of protein patterns, was sent to Mokwon University MicroEcological Resources Research Institute to conduct identification of the strain. The strain was analyzed with molecular genetic analysis based on the flagellin $\mathrm{C}$ gene, a specific gene in $B$. thuringiensis with $\mathrm{H}$ serotype, and as a result, the strain was classified into new subspecies of B. thuringiensis (Fig. 4).

Among B. thuringiensis strains, those strains that exhibit activity in Diptera produce important two kinds of insecticidal proteins including the Cry (Crystal protein) and Cyt (cytolytic toxin) proteins in the spore formation stage (Höfte and Whitely, 1989). B. thuringiensis subsp. israelensis strain, which is known to have high insecticidal activities in Diptera pests had six genes, which are cry4Aa, cry4Ba, cry10, cry11Aa, cyt1Aa, and cyt2Ba (Bravo et al., 2007). However, when the cry genes of $B$. thuringiensis strain CAB452, which was selected as it showed activity in Diptera, were checked, it could be seen that it had cry9D gene, which did not appear in B. thuringiensis subsp. israelensis strain that shows activity in mosquitos. In addition, it had cry4A gene, which is known to have activity in Diptera (Table 2). In addition, the production of cry9D and a new protein cry9 was reported in $B$. thuringiensis subsp. japonensis strain, reported to have activity in mosquito larvae (Wasano et al., 1998; Wasano et al., 2001). This gene is known to have insecticidal activities in Coleoptera. In this study, cry9D and cry4A gene bands were identified in B. thuringiensis strain CAB452 with insecticidal activities in Diptera.

B. thuringiensis strain CAB452 that shows activity in Diptera and B. thuringiensis subsp. israelensis strain could not be easily distinguished when observed through two types of microscopes because there was no difference in appearances but these strains showed clear differences in proteins and plasmid DNA patterns. $B$. thuringiensis strain CAB452 was reviewed as a new strain expressing insecticidal activities in $B$ agrestis and its potential as a new microbial insecticide could be identified.

Table 2. Profiles of cry genes in B. thuringiensis strains

\begin{tabular}{cc}
\hline Strain & Crystal protein \\
\hline B. thuringiensis subsp. & cry9D, cry $4 A$ \\
CAB452 & cry $4 A a$, cry $4 B a$, cry $10 A a$, \\
B. thuringiensis subsp. & cry11Aa, cyt1Aa, cyt2Ba \\
\hline
\end{tabular}

\section{AUTHOR CONTRIBUTIONS}

Hee Ji Kim designed the study, performed the isolation of new $B$. thuringiensis strains, the comprehensive experiments, analyzed the data and wrote the paper. You Kyung Lee participated in the pest control experiments. Young Nam Youn edited the paper. Chisa Yasunaga-Aoki participated in the design of the study and discussed on the experiments and the results. Yong

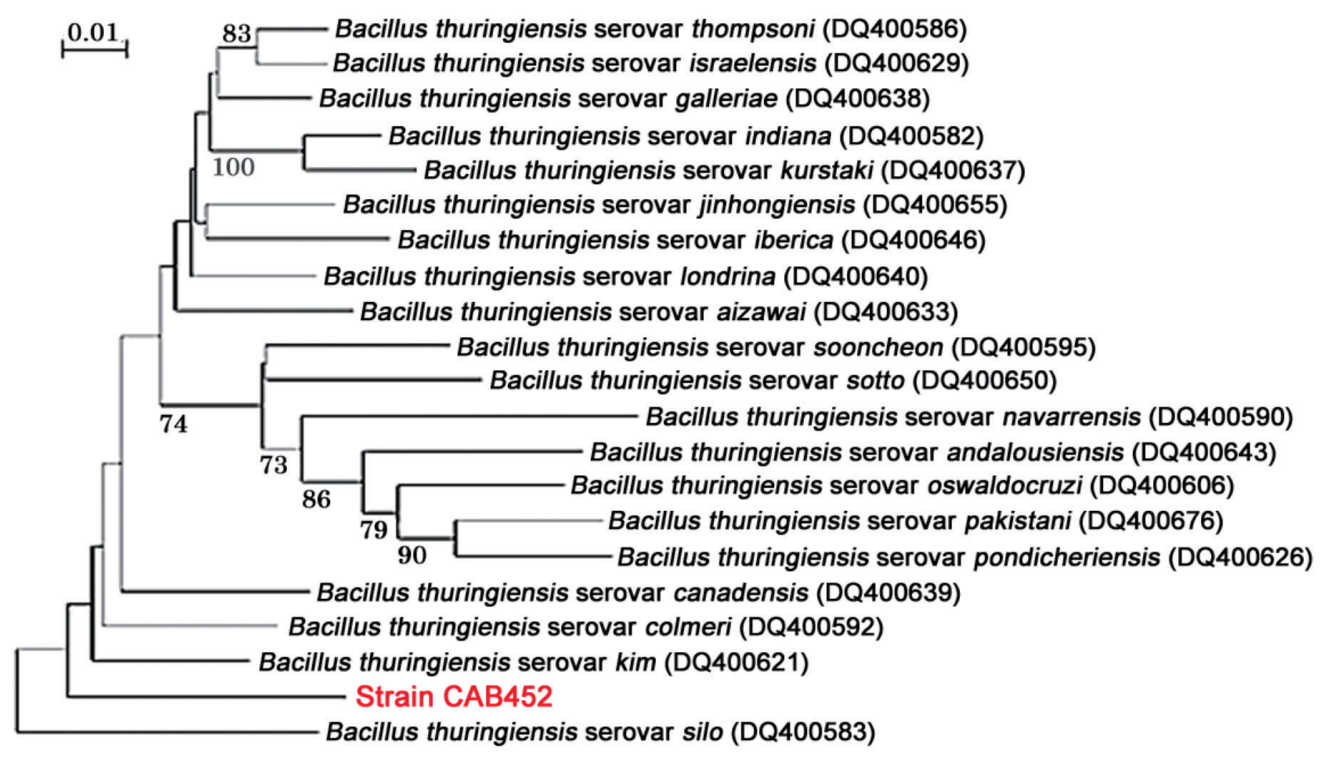

Fig. 4. Phylogenetic tree based on flagellin $C$ gene sequences showing the position of Strain $B$. thuringiensis CAB452 and related bacterial taxa. 
Man Yu supervised the work and wrote the paper. All authors assisted in editing of the manuscript and approved the final version.

\section{REFERENCES}

Binns, E. S. 1973 Fungus gnats (Diptera: Mycetophilidae, Sciaridae) and the role of mycophagy in soil: a review. Revue d'Ecologie et de Biologue du Sol, 18: 77-90

Bravo, A., S. S. Gill and M. Sobero 2007 Mode of action of Bacillus thuringiensis cry and cyt toxin and their potential for insect control. Toxicon., 49: 423-435

Harris, M. A., R. D. Oetting and W. A. Gardner 1995 Use of entomopathogenic nematodes and a new monitoring technique for control of fungus gnats, Bradysia coprophila (Diptera:Sciaridae), in floriculture. Biol. Control., 5: 412-418

Höfte, H. and H. R. Whitely 1989 Insecticidal crystal proteins of Bacillus thuringiensis. Microbiol. Rev., 53: 242-255

Ibarra, J. E. and B. A. Federici 1986a Isolation of a relatively non-toxic 65 -kilodalton protein inclusion from the parasporal body of Bacillus thuringiensis subsp. israelensis. J. Bacteriol., 165: 527-533

Ibarra, J. E., M. C. del Rincon, S. Orduz, D. Noriega, G. Benintende, R. Monnerat, L. Regis, C. M. de Oliveira, H. Lanz, M. H. Rodriguez, J. Sanchez, G. Pena and A. Bravo 2003 Diversity of Bacillus thuringiensis strains from Latin America with insecticidal activity against different mosquito species. Appl. Environ. Microbiol., 69: 5269-5274

Ibarra, J. E. and B. A. Federici 1986b Parasporal bodies of Bacillus thuringiensis subsp. morrisoni (PG-14) and Bacillus thuringiensis subsp. israelensis are similar in protein composition and toxicity. FEMS Microbiol Letters., 34: 79-84

Jagdale, G. B., M. L. Casey, P. S. Grewal and R. K. Lindquist 2004 Application rate and timing, potting medium, and host plant effects on the efficacy of Steinernema feltiae against the fungus gnat, Bradysia coprophila, in floriculture. Biol. Control., 29: $296-305$

Jang, H. J., H. Yoon, H. R. Kwon, Y. M. Yong and Y. M. Youn 2018 Mass-rearing Method of the Fungus Gnat, Bradysia difformis (Sciaridae, Diptera) in Laboratory. Kor. J. Appl. Entomol., 57: $57-64$

Jeon, H. Y., J. A. Jung, T. J. Kang, C. Y. Yang and H. H. Kim 2007 Damage Status of Poinsettia by the Fungus Gnat (Bradysia difformis) and Its control with Predatory Mite (Hypoaspis aculeifer). Kor. J. Hort. Sci. Technol., 25: 468-473

Kim, H. H., M. R. Cho, T. J. Kang, S. J. Ahn, S. W. Jeon, C. J. Lee and J. C. Cheong 2012 Damage and biological control of dark winged fungus gnats, Lycoriella ingenua (Diptera: Sciaridae) in a shiitake cultivation. J. Mush. Sci. Prod., 10: 184-190

Kim, H. H., H. Y. Choo, H. S. Lee, C. G. Park, D. W. Lee, B. R. Jin and Y. M. Choo 2001 Biological control of Lycoriella mali (Diptera: Sciaridae), a pest of oyster mushroom, Pleurotus ostreatus using entomopathogenic nematodes. Kor. J. Appl. Entomol., 40: 59-67

Kim, D. A., J. S. Kim, M. R. Kil, S. K. Paek, S. Y. Choi, D. Y. Jin, Y. N. Yoon, I. C. Hwang and Y. M. Yu 2008 Characterization of new
Bacillus thuringiensis isolated with bioactivities to tobacco cutworm, Spodoptera litura (Lepidoptera: Noctuidae). Kor. J. Appl. Entomol., 47: 87-93

Kim, H. H., D. H. Kim, C. Y. Yang, S. J. Kwon, S. W. Jeon, J. S. Song, M. R. Cho, C. J. Lee and J. C. Cheong 2013 Biological control of mushroom flies using the predatory mite Hypoaspis aculeifer in a shiitake cultivation. J. Mush. Sci. Prod., 11: 230-239

Laemmli, U. K. 1970 Cleavage of structural proteins during the assembly of the head of bacteriophage T4. Nature., 227: 680685

Lee, Y. K., N. Y. Jin, J. H. Jun, Y. S. Kim, B. R. Lee, M. J. Seo, Y. N. Youn and Y. M. Yu 2014 Isolation and characterization of new Bacillus thuringiensis strains with insecticidal activity to difficult to control lepidopteran pests. J. Fac. Agr. Kyushu Univ., 60: $103-112$

Lee, Y. K., N. Y. Jin, B. R. Lee, M. J. Seo, Y. N. Youn, C. YasunagaAoki and Y. M. Yu 2015 Isolation and characterization of new Bacillus thuringiensis strains with insecticidal activity for difficult to control lepidopteran pests. J. Fac. Agr. Kyushu Univ., 60: $103-112$

Lee, H. S., T. S. Kim, H. Y. Shin, H. H. Kim and K. J. Kim 2001 Host plant and damage symptom of fungus gnats, Bradysia spp. (Diptera: Sciaridae) in Korea. Kor. J. Appl. Entomol., 40: 149153

Lindquest, R. K., W. R. Faber and M. L. Casey 1985 Effect of various soilless root media and inseticides on fungus gnats. Hortsci., 20: $358-360$

Ludwig, S. W. and R. D. Oetting 2001 Evaluation of medium treatments for management of Frankliniella occidentalis (Thripidae: Thysanoptera) and Bradysia coprophila (Diptera: Sciaridae). Pest Manag. Sci., 57: 1114-1118

Park, C. G., J. Yoo, M. Sasakawa, H. Y. Choo, H. H. Kim and H. S. Lee 1999 Notes on newly recorded insect pest, Bradysia agrestis Sasakawa (Diptera: Sciaridae). Kor. J. Appl. Entomol., 38: $59-62$

Schnepf, H. E. 1995 Bacillus thuringiensis toxins: regulation, activities and structural diversity. Curr. Opin. Biotechnol., 6: 305-312

Seo, M. J., Y. J. Gil, T. H. Kim, H. J. Kim, Y. N. Youn and Y. M. Yu 2010 Control effects against mosquitoes larva of Bacillus thuringiensis subsp. israelensis CAB199 isolate according to different formulations. Kor. J. Appl. Entomol., 49: 151-158

Wasano, N., K. H. Kim and M. Ohba 1998 Delta-endotoxin proteins associated with spherical parasporal inclusions of the four Lepidoptera - specific Bacillus thuringiensis strains. J. Appl. Microbiol., 84: 501-508

Wasano, N., M. Ohba and K. Miyamoto 2001 Two $\delta$-endotoxin genes, cry9Da and a novel related gene, commonly occurring in Lepidoptera-specific Bacillus thuringiensis Japanese isolates that produce spherical parasporal inclusions. Curr. microbiol., 42: $129-133$

WHO 2005 Guidelines for laboratory and field testing of mosquito larvicides. World Health Organization., 13: 1-41

Yang, Z., H. Chen, W. Tang, H. Hua and Y. Lin 2011 Development and characterization of transgenic rice expressing two Bacillus thuringiensis genes. Pest manag. sci., 67: 414-422 
